Amasya Ilahiyat Dergisi - Amasya Theology Journal

ISSN 2667-7326 | e-ISSN 2667-6710

Haziran / June 2021, 16: 365-394

\title{
Vicdanlı Nesilden Vicdanlı Topluma
}

\author{
Nedim ÖZ \\ Dr. Öğr. Üyesi, Kilis 7 Aralık Üniversitesi, İlahiyat Fakültesi, \\ Din Sosyolojisi Anabilim Dalı \\ Assistant Professor, University of Kilis 7 Aralık, Faculty of Theology, \\ Department of the Sociology of Religion \\ Kilis, Turkey \\ nedimoz@kilis.edu.tr \\ orcid.org/0000-0002-4481-0297 \\ Makale Bilgisi / Article Information \\ Makale Türü / Article Types: Araştırma Makalesi / Research Article \\ Geliş Tarihi / Received: 14 Ocak / January 2021 \\ Kabul Tarihi / Accepted: 14 Nisan / April 2021
}

Yayın Tarihi / Published: 30 Haziran / June 2021

Yayin Sezonu / Pub. Date Season: Haziran / June

Sayı / Issue: 16 Sayfa / Pages: 365-394

Atıf / Cite as: Öz, Nedim. "Vicdanlı Nesilden Vicdanlı Topluma [From Conscientious Generation to A Conscientious Society]". Amasya Ilahiyat DergisiAmasya Theology Journal 16 (June 2021): 365-394.

https://doi.org/10.18498/amailad.861229.

İntihal / Plagiarism: Bu makale, en az iki hakem tarafından incelendi ve intihal içermediği teyit edildi. / This article has been reviewed by at least two referees and scanned via a plagiarism software.

Copyright ( Published by Amasya Üniversitesi, İlahiyat Fakültesi / Amasya University, Faculty of Theology, Amasya, 05100 Turkey. All rights reserved. https://dergipark.org.tr/amailad. 
366 | N. ÖZ / Vicdanlı Nesilden Vicdanlı Topluma

\section{From Conscientious Generation to A Conscientious Society}

\section{Abstract}

Referring to meanings such as "inner sense, consciousness", conscience is a moral feeling that is associated with intuition, being pleased with doing good deeds, feeling uneasy due to committing a crime, differing good from bad, benevolence from evil. This selective and distinguishing faculty is called conscience. For this reason, it has good or bad effects on a human being's deeds and actions. Conscience assumes the role of "auto-control" in all deeds of a person. Although not mentioned in Qur'an, the conscience is used in many places in the same meaning as self, heart and nature, which supervise willful actions of a human being under moral standards. In this study, conscientiousness and unscrupulousness have been handled with the documentation method from a socio-religious perspective on the basis of family and surrounding and discussed theoretically. The aim is to reveal that society becomes conscientious through the conscientiousness of individuals and the social importance of this process.

No human being has innate negative characteristics, such as unscrupulousness, intolerance and disrespect against any other human being different from him/her in terms of religious, ethnic, cultural respect. If it were, it can not be stated about the material and spiritual cultural elements created by people and the effect of this culture on them by the transfer of this culture to new generations. It is known that each human being is born into a culture and lives by internalizing that culture, thereby continuing his/her socialization. Based on this perspective, the importance of education in the formation of a culture of conscientiousness can be better understood. In other words, unscrupulousness, mercilessness, intolerance are learned actions. Our innate conscience develops or regresses in accordance with the environment we live in and our experiences. While the conscience of an individual completing his/her socialization process with positive values and norms in positive environments develops, the conscience of an individual experiencing the opposite situation has a negative development course. Accordingly, it is necessary for a pure conscience to believe and to stay virtuous. Although a human being is equipped with superior skills, s/he has the capacity for good and bad deeds, thus, sometimes achieves supreme ranks and sometimes falls to the lowest degrees. If the nature of individuals is protected, societies will be comprised of conscientious people, otherwise, societies will consist of individuals who are intolerant, unscrupulous. This will be formed as a result of the mental, physical and moral processes of an individual. Human being is not 
an idle creature. $\mathrm{S} /$ he has duties and responsibilities for himself/herself, his/her family, society and even all humanity. The most important of these is to act with a sense of responsibility towards the Absolute Being and all the creatures it creates. In order to gain this consciousness, it is necessary to socialize in the family and environmental factors, that is, to gain feelings and values such as conscience, mercy, compassion, loyalty and justice. In this respect, family is of primary importance. As the child first imitates and identifies with emotions and behaviors, the family becomes a place where values such as conscience, compassion, respect and love are gained, or where strife, conflict and ruthlessness are learned. Among these, negative values cause the formation of negative society, positive values cause the formation of positive society type. As an educational institution, the goal of a family is to build a peaceful society by providing new generations positive values and raising individuals who avoid all forms of harassment and offence. Schools, teachers, relatives, peer groups, books, novels, stories read, mass media and series that form environmental instruments in the socialization process have of paramount importance in children's positive and negative personality characteristics. Therefore, if all these instruments based on the benefit for a human being, his/her education, raising him/her as a characterful individual, a society, in which violence, extortion, killing and similar actions are not seen, but consisting of conscientious and merciful individuals loving each other, respecting their rights, competing for doing a good deed for each other.

Keywords: Sociology of Religion, Conscience, Society, Family, Environment.

\section{Öz}

\section{Vicdanlı Nesilden Vicdanlı Topluma}

"İç duygusu, şuur", gibi manalara gelen vicdân, terim olarak insanın kalbine doğan bir his, hayır işlemekten hoşlanan, kötülük etmekten huzursuz olan iyiyi kötüden, hayrı şerden ayıran ahlaki duygudur. Bu seçici ve ayırt edici melekeye vicdan denilmektedir. Bu yüzden o, insanın fiil ve davranışları üzerinde müspet ya da menfi bir tesire sahiptir. Vicdan kişinin bütün işlerinde "oto kontrol" görevini üstlenmektedir. Vicdan Kur'an'da geçmemekle birlikte birçok yerde insanın iradeye dayalı eylemlerini ahlâki ölçüler çerçevesinde denetleyen nefis, kalp ve fıtrat ile aynı anlamda kullanılmaktadır. Bu çalışmada, vicdanlılık ve vicdansızlık aile ve çevre ekseninde sosyo-dini perspektifle dökümantasyon yöntemiyle ele alınmış ve teorik olarak tartışılmıştır. Amaç, toplumun vicdanlı 
hale gelmesinin bireylerin vicdanlılığından geçtiğini ve bu sürecin toplumsal açıdan önemini ortaya koymaktır.

Hiçbir insan dünyaya gelirken din, etnik, kültürel yönlerden kendinden farklı olanlara karşı vicdansız, hoşgörüsüz ve saygısızlık gibi olumsuz niteliklere sahip değildir. Öyle olsaydı, insanların oluşturmuş olduğu maddi ve manevi kültür unsurlarından ve kültürün yeni kuşaklara aktarılması ile onlar üzerindeki etkisinden söz edilemezdi. Bilmekteyiz ki, insan bir kültürün içerisine doğmakta ve kültürü içselleştirerek yaşamakta ve böylece sosyalleşmesini sürdürmektedir. $\mathrm{Bu}$ perspektiften bakılınca vicdanlılık kültürünün oluşmasında eğitimin önemi daha iyi kavranabilir. Başka bir deyişle vicdansızlık, merhametsizlik, hoşgörüsüzlük öğrenilmiş bir davranıştır. Doğuştan getirdiğimiz vicdan, içinde bulunduğumuz çevre ve yaşantılarımız ile gelişir ya da geriler. Olumlu ortamlar içerisinde müspet değerler ve normlarla sosyalleşme sürecini tamamlayan bireyin vicdanı gelişirken, aksi bir durumu yaşayan kişinin vicdanı ise olumsuz bir gelişme seyri izler. Dolayısıyla vicdanın sağlam kalması, bozulmaması için inanmaya ve kirletilmemeye ihtiyacı vardır.

İnsan, üstün yeteneklerle donatılmış olmasına rağmen iyiliğe ve kötülüğe yönelebilmekte, bazen yüce mertebelere çıkarken bazen en aşağı derekelere düşebilmektedir. İnsanın, fıtratı korunursa vicdanlı bir kişi, bu kişilerden oluşan bir toplum; fıtratı korunamadığında ise, hoşgörüsüz, vicdansız bir kişi ve bu kişilerden meydana gelen bir toplum ortaya çıkar. Bu da bireyin zihinsel, fiziksel ve ahlaki süreçlerinin sonucunda ortaya çıkacak bir durumdur. İnsan başıboş bir varlık değildir. Onun kendisine, ailesine, toplumuna hatta tüm insanlara karşı görev ve sorumlulukları vardır. Bunlardan en önemlisi başta Mutlak Varlığa ve yarattığı bütün mahlûkata karşı sorumluluk bilinciyle hareket etmektir. Bu bilinci kazanılabilmesi için insanın ailede ve çevresel faktörler içerisinde sosyalleşmesi, vicdan, merhamet, acıma, sadakat ve adalet gibi duygu ve değerlerin kendisine kazandırılması gerekmektedir. Bu noktada aile, birincil derecede önemlidir. Çocuğun ilk taklit ettiği ve özdeşim kurduğu duygu ve davranış yüklü ortam olması hasebiyle aile, vicdanın, merhametin, saygı ve sevgi gibi değerlerin kazanıldığı yahut da çekişmenin, çatışmanın, acımasızlığın öğrenildiği bir yer olur. Bunlardan olumsuz değerler olumsuz toplumun, olumlu değerler de olumlu toplum tipinin oluşmasına neden olmaktadır. Bir eğitim kurumu olarak ailenin hedefi, yeni nesillere olumlu değerleri kazandırarak onları her türlü taciz ve tecavüzden uzak bireyler yetiştirmek suretiyle huzurlu bir toplum inşa etmektir. Sosyalizasyon sürecinde çevresel 
enstrümanları oluşturan okul, öğretmen, akraba, akran gurupları, okunan kitap, romanlar, hikâyeler, kitle iletişim araçları ve diziler çocuklara olumlu veya olumsuz şahsiyet özelliklerini kazandırmada büyük bir öneme sahiptir. Dolayısıyla bütün bu araç-gereçler, insana faydayı ve onun eğitimini, karakterli şahsiyet olarak geliştirilmesini esas alırsa, şiddet, gasp, öldürme vb. davranışlardan uzak, birbirini seven, hak ve hukukuna riayet eden, birbirlerine iyilik etmekte yarışan vicdan ve merhamet sahibi bir toplum meydana gelmiş olur.

Anahtar Kelimeler: Din Sosyolojisi, Vicdan, Toplum, Aile, Çevre.

\section{Giriş}

İnsanoğlu, maddi ve manevi boyutları itibariyle karmaşık yapıya sahip bir varlık olarak dünyaya gelmiştir. Kendisi dışındaki varlıklara göre üstün kabiliyet ve yeteneklerle dünyaya gelen insan, sahip olduğu bu kabiliyetlerini kullanarak bireysel ya da toplumsal yaşam içinde hayatını devam ettirmektedir. Diğer varlık türlerinden farklı bir biçimde iyiye ve kötüye de kabiliyetli kılınmak suretiyle, aşağıların en aşağısına düşebilecek veya yücelerin en yücesine çıkabilecek bir potansiyeli içinde taşımaktadır. Bu bağlamda doğası gereği yanlışa düşme ihtimali olan, vicdansız veya merhametsiz tabir edilen insan, temiz fitratıyla ve her şeyin iç yüzünü bilen Allah'la doğrudan iletişim kurabilmekte midir veya O'nunla kurulan iletişim vahiy üzerinden mi gerçekleştirilmektedir? Bu iletişim ve sonuçları ne kadar sağlıklı bir süreç izlemektedir? Zira hiçbir insan, vicdansızlığı ve merhametsizliği yaratılışından getirmez. Bu, sosyalleşme sürecinde kazanılan benlik ya da kişilik yapısıyla ilgilidir. Kişilik ise, kalıtsal özellikler ve çevrenin ortak ürünüdür. ${ }^{1}$ Başka bir deyişle insan biyolojik, psikolojik, sosyo-kültürel ve ekonomik bir varlık olması yanında, o aynı zamanda belli mekânlarda yaşayan, belli bir zaman sürecinde hayat süren ve inançları olan bir varlıktır. ${ }^{2}$ Dolayısıyla kişinin benliği, çocuk doğduğu andan itibaren başından geçen sayısız olaylarla, çevresinde ilişki kurduğu kişilerin etkisiyle yavaş yavaş oluşmaktadır.

1 Kemal Sayar - Mehmet Dinç, Psikolojiye Giriş (İstanbul: Dem Yayınları, 2014), 96.

2 Zeki Arslantürk - Mehmet Tayfun Amman, Sosyoloji (İstanbul: Çamlıca Yayınları, 2013), 144. 
Eğitimin en önemli hedefi fertlerin yetiştirilmesi ve buna bağlı olarak toplumu huzurlu, uyumlu bir hale ulaştırmaktır. Dolayısıyla gençlikten ihtiyarlığa kadar hemen her fert, kültür ve terbiye konusunda az veya çok başkalarına borçludur, onlara ihtiyaç duyar. Eğer küçük yaşlardan itibaren fertler, fitratları bozulmadan doğru ve iyi yetiştirilir yani şefkat, merhamet, empati duygusu ön planda olursa, elbette saldırganlıktan, çatışmadan, kavgadan, şiddet yanlısı veya vicdansız olmaktan uzak durur. Aksi takdirde, o saf, temiz, uysal bir fitratta yaratılmış olan insan, merhametten, vicdandan yoksun olarak kan döken, can yakan bir canavara dönüşebilir. Bu yüzdendir ki insan başıboş bir varlık değildir. ${ }^{3}$ Bunun için, G. H. Mead'in kuramına göre; düşünen, bilinçli birey ve nesillerden önce bir toplumsal grubun bulunması gerekir ki insanlar arasında iletişim olabilsin. Bireyin doğuştan getirmediği benlik, onun deneyimlediği sosyal ilişkiler sonrasında ortaya çıar. Zira benlik, toplumsal etkinlik ve toplumsal ilişkiler aracılığıyla oluşturulur. Diğer bir ifadeyle bir benliğe sahip olmak, bir toplumun üyesi olmayı, topluluğa mahsus tutumlar tarafından yönlendirilmeyi gerektirir. ${ }^{4}$ Mead'e göre birey aktif bir öznedir; hem kendini çevreye uyarlar hem de çevreyi etkiler ${ }^{5} \mathrm{ki}$ bu çift yönlü bir etkileşimdir. Onun içindir ki insanın, sosyalleşme süreçlerinde sürekli iyiliğe teşvik edilmesi, iyi örneklerle buluşturulması gerekmektedir. Zira kendi kişisel arzu ve istekleri ile baş başa bırakılırsa davranışlarını yanlış yönlendirme, değerlendirme eğilimi gösterir; bu da onun, hem birey olarak kendisine, ailesine, komşularına hem de bütün bir topluma zararlı bir varlık haline gelmesine yol açar.

Vicdansızlığın, insanlık tarihi kadar eskiye gittiği görülmektedir. Bu gün, gündelik hayatımızın çeşitli veçhelerinde tezahürlerini görmeye alıştığımız vicdansızlık olgusunu, Kutsal kitabımızda Âdem'in iki oğlunun ${ }^{6}$ kıssası anlatılırken, insanlık ailesinin başlangıcında, Habil'e

3 Kur'ân-ı Kerìm Meali, çev. Halil Altuntaş - Muzaffer Şahin (Ankara: Diyanet İşleri Başkanlığı Yayınları, 2006), el-Kıyame, 75/36.

4 George Ritzer, Modern Sosyoloji Kuramları (Ankara: De Ki Basım Yayınları, 2011), 215223; Ruth A. Wallace - Alison Wolf, Çă̆gaş Sosyoloji Kuramları, çev. Leyla Elburuz - M. Rami Ayas (Ankara: Doğu Batı Yayınları, 2012), 277; Arslantürk - Amman, Sosyoloji, 165.

5 George Herbert Mead, Zihin, Benlik ve Toplum, çev. Yeşim Erdem (Ankara: Heretik Yayınları, 2017), 230.

6 Güngör Karauğuz, Âdem'in Çocukları (Konya: Çizgi Kitabevi, 2013), 95. 
karşı Kabil'in tutum ve tavrında da gözlemlemekteyiz. ${ }^{7}$ Sözgelimi: Habil “... sen öldürmek için bana elini uzatsan bile ben sana, öldürmek için el uzatacak değilim..."8 diyerek insanın ontolojik manada üstün bir varlık olduğu, Allah'ın verdiği canı O'ndan başkasının alamayacağı ve bundan dolayı hoş görülmesi gerektiğini ifade etmiştir. Bu yaklaşımıyla Habil, bir sembol olarak, o gün itibariyle insanlara vicdanlı davranma ve onları hoş görebilme olgunluğunun ilk örneği sınavını başarıyla vermiştir. Bu itibarla Habil vicdanlı olmanın, hoşgörünün temsilcisi, vicdansızlık ve hoşgörüsüzlüğün temsilcisi ise şeytana uyan Kabil olmuştur. ${ }^{9}$ Ayrıca, insanların dünyaya gelirken hiçbir bilgiye sahip olmadıkları; kendilerine şükretme ve küfretme imkânı verecek olan kulak, göz ve gönüllerin yani bilgi edinme vasıtalarının hazır bir biçimde verildiği belirtilmektedir. ${ }^{10}$ Insanlar doğuştan vicdansız, dini, etnik, cinsiyet yönünden farklı olanlara karşı önyargılı ve saldırgan olmadığına göre niçin insanlar hemcinslerine ve diğer varlık türlerine karşı vicdanlı olmak yerine vicdansız davranmaktadırlar? Her şeyden önce üstün bir istidada sahip kılınan ve yeryüzünde Allah'ın halifesi olarak düşünen, konuşan, üreten ve eşyaya anlam vererek yaşayan insan, nasıl oluyor da dünyada kan döken, şiddete yönelen, yırtıcı ve korkunç bir varlık da olabilmektedir. Değer atfedilen vicdanlı olmayı bir tutum olarak benimseyip ona göre davranan bireyler yetiştirmek ve vicdansızlığı, hoşgörüsüzlüğü önlemek mümkün müdür? Acaba bunun için neler yapılmalıdır? Toplum olarak bu vb. soruların cevabını bulma zorunluluğumuz vardır.

Günlük konuşmalarımızda, sosyal hayat içerisinde en sık kullanılanlardan birisi "vicdan" kavramıdır. "Vicdan rahatlığı", "vicdanın rahat mi?", "vicdanin ne kadar rahat", "benim vicdanim rahat" ya da "gece yastığa başını rahat koyabiliyor musun?" gibi müspet çağrışım yapan ifadeler, aynı zamanda "vicdansızlık" denilen menfi anlamından uzak durmaya da işaret etmekte ve aslında hep aynı noktaya yani "vicdanlı olma" noktasına gönderme yapmaktadır. İnsanın en temel gücü olan bu içsel güç, bir şekilde hasar görmeden varlığını sürdürebilmelidir. Eğer bir hasar söz konusu ise "vicdanın

\footnotetext{
7 el-Maide 5/27-31.

8 el-Maide 5/28.

9 el-Maide 5/27-31.

10 en-Nahl 16/78.
} 
körelmesi"nden bahsedilir. Onu harekete geçiren ve etkileyen bir şey olmuşsa "vicdanın yaralanması, sızlaması" ile "vicdan azabı çekmek", "vicdanının sesini dinlemek" gibi daha pek çok şekilde kullanılan "vicdan" kavramının, davranışları denetleyen ve insanı "insan" yapan önemli değerlerden biri olduğu görülmektedir. ${ }^{11}$

Temel problem, söz konusu bu önemli değerin, benlik ve kişiliğin oluşması süreci olan ailede ve çevrede, nasıl inşa edildiği veya edilmediğidir. $\mathrm{Bu}$ problem, çalışmada sosyolojik perspektiften dokümantasyon yöntemiyle ele alınmaktadır. Amaç, sosyalleşme sürecinde mikro planda bireysel vicdanın inşası ve böylece makro planda vicdanlı bir toplumun tezahürüdür. Buna göre, gerek anne-baba gerekse diğer yetişkinler, çocuğa daha çok erken yaşlarda ne olması, ne olmaması lazım geldiğini bilgi olarak aktarırken, davranışlarıyla da model olurlar. Ona hangi şahsi özelliklerin arzu edilir veya iyi olduğunu, hangi özelliklerin de arzulanmadığını veya kötü olduğunu süreç içerisinde kazandırırlar. Kültüre ait değerlerin bu şekilde öğrenilmesi sonucunda çocuk ne olması lazım geldiğine dair bir mefhum edinir ve geliştirir ki bu da onun ideal benini teşkil der. Cooley bu durumu, "Herkes herkesin aynasıdır. Bu ayna önünden geçeni onun sosyal sınıfına göre aksettirir" hipotezi ile ifade etmektedir. ${ }^{12} \mathrm{Bu}$ perspektiften hareketle çalışmada, önce vicdan ve kapsamı, nasıl geliştiği, daha sonra toplumsal açıdan ailede ve diğer çevre unsurları içerisinde gelişimini sürdüren vicdanlı nesiller vasitasıyla, vicdan ve merhametin daha ön planda olduğu toplumun teşekkülü konusu ele alınmaktadır. Amaç, sözkonusu bireyler ve onlardan teşekkül etmiş olan toplumun şiddet, çatışma vb. uzak, uyum, huzur ve mutlulk içinde yaşamasıdır.

\section{Vicdan Kelimesi ve Kapsamı}

Sözlükte "bulmak, zenginleşmek, sevmek, üzülmek, öfkelenmek" anlamlarındaki vecd kökünden masdar olan vicdân ve aynı kökten vücdân, cide gibi kelimeler "bolluk, rahatlık, zenginlik", vecd ise "üzüntü", ayrıca "sevgi"; ${ }^{13}$ vicdân "iç duygusu, şuur", "bir şeyi bir halde görme; duygu ve kalp ile hissetme" gibi manalara gelmektedir. Terim

11 Osman Demir, "Vicdan", Türkiye Diyanet Vakfi İslâm Ansiklopedisi (Ankara: TDV Yayınları, 2013), 43/102.

12 Arslantürk - Amman, Sosyoloji, 167.

13 Demir, "Vicdan", 43/100. 
olarak vicdân, insanın kalbine doğan gizli bir his olup iyilik, hayır işlemekten hoşlanan, kötülük etmekten huzursuz olan ve ondan sakınan, iyiyi kötüden, hayrı şerden ayıran ve seçici bir yapıya sahip olan ahlaki duygudur. ${ }^{14}$ Diğer bir deyişle vicdan "insanın içinde bulunan ahlâkî otorite, ahlâkî değerler ve eylemler hakkında hüküm verme, yargılama yeteneğini ifade eder."15 Aslında iyi-kötü, güzel-çirkin ile yararlı ve zararlı olanı birbirinden ayıracak olan bir melekeyi, Allah insanın yaratılışına yerleştirmiştir. ${ }^{16}$ İşte vicdan, insandaki bu seçici, ayırt edici melekedir. Onun insan fiil ve davranışları üzerinde müspet ya da menfi tesiri söz konusudur. Yani vicdan kişinin gizli ve açık bütün işlerinde "oto kontrol" görevi yapar. Bu manada vicdan, bir iç duygu, ahlak şuuru ${ }^{17}$ anlamina gelirken; "vicdanlı" kavramı bir sıfat olarak, vicdanı olan, hak gözeten, aciyan ve merhamet eden, insaflı anlamina gelmekte, "vicdansız" sıfatı ise, vicdanı olmayan, acımasız, hak gözetmeyen, insafsız anlamlarına gelmektedir. ${ }^{18}$ Burada fertlerin, içinde yaşadığ toplumun kültür değerlerine uygun ${ }^{19}$ biçimde gelişim gösterdiği söylenebilir.

Vicdan kelimesi Kur'an'da geçmemekle birlikte birçok yerde insanın iradeye dayalı eylemlerini ahlâki ölçüler çerçevesinde denetleyen, iyilikten hoşnut olan ahlâkî melekedir ki, tövbe de aslında böyle bir vicdanî hesaplaşma ve muhasebenin ürünü olarak görülmektedir. ${ }^{20}$ Kur'an'da en çok geçen kelimelerden nefis, insanın psikolojik yapısıyla ilgili ve tesir bakımından vicdanı da kapsayan geniş bir anlam yelpazesine sahiptir. İnsanın kişilik ve benliğini oluşturan, nefsin

14 Fikret Karaman, Dini Kavramlar Sözlü̆g̈̈̈ (İstanbul: Diyanet İşleri Başkanlığı Yayınları, 2009), “Vicdan”, 602; Muhiddin Bağçeci, “Vicdan”, Şamil İslam Ansiklopedisi (İstanbul: Şamil Yayınevi, 2000), 8/234; Ahmet Nedim Serinsu vd. Din̂̂ Terimler Sözlüğ̈̈̈ (Ankara: Milli Eğitim Bakanlığı Yayınları, 2009), “Vicdan”, 385.

15 Demir, "Vicdan", 43/100.

16 eş-Şems 90/18.

17 Mustafa Çağrıcı, Anahatlarıyla İslam Ahlakı (İstanbul: Ensar Neşriyat, 2000), 168.

18 D. Mehmet Doğan, Büyük Türkçe Sözlük (İstanbul: İz Yayıncılık, 1996), "Vicdansız", 1117.

19 Hayati Hökelekli, Din Psikolojisi (Ankara: TDV Yayınları, 2020), 118.

20 Bk. en-Nisa 4/17-18; el-Maide 5/38-39; en-Nahl 16/119. 
çeşitlerinden söz edilir ki, bunlara "nefs-i emmare", ${ }^{21}$ "nefs-i levvame" 22 , "nefs-i mutmainne" 23 denmektedir. Buna göre nefsin, vicdanî yönü ile kendini denetleme yetkisine sahip ${ }^{24}$ olduğu, nefsini arındıranın ebedî kurtuluşa ereceği, onu kirletenin ise ziyana uğrayacağını ifade eden ${ }^{25}$ nefis kelimesi de vicdanı hatırlatmaktadır. Kur'an'da yine en çok kullanılan kalp kelimesi vicdan anlamına da gelmektedir. Buna göre "kalb-i selîm" 26 vicdanı nitelemekte ve Peygamber'in insanlara karşı nezaketli bir biçimde davrandığına işaret eden "galîzu'l-kalb" (katı kalpli) ifadesine ${ }^{27}$ Türkçe'de "acımasız, vicdansız" anlamı vermek mümkündür. "Fitrat" ise, insanın hakkı benimsemeye yatkınlığını belirten bir kavram olarak vicdanı da kapsamaktadır. ${ }^{28}$ Vicdan kavramına, hadislerde çoğunlukla kalp kelimesi çerçevesinde temas edilmektedir. Bu manada güzel ve hayırlı işler kalbe huzur verirken, kötü iş ve davranışlar onu rahatsız etmektedir ${ }^{29}$ ve fitraten insanın temiz bir vicdana sahip olduğu belirtilmektedir. Nefis ve kalp kelimeleri, genellikle klasik İslâmî literatürde de, vicdan kavramı karşılığında kullanılmıştır. ${ }^{30}$ Burada asıl önemli olan husus, bu kavramsal anlamları toplumun üyelerine aktarmak suretiyle toplumsal bütünleşmeye ve huzura katkı sunmaktır.

İnsan vücudunda fizyolojik olaylardan başka, ruhi hadiseler denilen şuur ve iradeyle birlikte iyilik, adalet, güzellik, hayır ve fazilete temayül; nefret, sevgi, güven hissi; hayâ, insaf, merhamet, vicdan azabı; inanç olmasa bile, özellikle darda kaldığında Allah'a sığınma ve yalvarma

21 Nefs'in ben merkezci ve hazci durumunu ifade eder. Yusuf 12/35.

22 Nefs'in kendini sorgulama durumunu ifade eder. el-Kıyame 75/2; Gürbüz Deniz, Anlam ve Varlık Boyutuyla İnsan (Ankara: DİB Yayınları, 2015), 48.

23 Nefs'in dini ve ahlaki değerlerle uyumlu en üst basamağını ifade eder. el-Fecr 89/2728.

24 el-Enbiya 21/64; en-Neml 27/14.

25 eş-Şems 91/7-10.

26 eş-Şuarâ 26/89.

27 Âl-i İmrân 3/159.

28 er-Rûm 30/30; Demir, "Vicdan", 100.

29 Ebû Abdilleh Ahmed b. Muhammed b. Hanbel eş-Şeybânî Ahmed b. Hanbel, elMüsned (Riyad: Beytü'l-Efkar, 1419/1998), 4/182, 227, 228; Ebü'l-Hüseyn Müslim b. elHaccâc Müslim, el-Câmi'ü's-Sahîh (Beyrut: Daru'l-Fikr, 1424/ 2003), “Birr”, 14-15.

30 Demir, "Vicdan", 43/100. 
gibi duygular vardır. Bunlar insan ruhundan, vicdanından kaynaklanmaktadır. Zira vicdan, ruhun sesidir. ${ }^{31}$ Bir de nefes/can vardır ki canlılık faaliyetlerini yürütmektedir. "Hayvani nefis" de denilen ve bedenin ihtiyaçlarını ifade eden bu yön, insan ve diğer canlılarda ortaktır. Nefsi natıka (insani nefis) denilen ruh ise, yalnız insanlara özgüdür. Ruhun başlıca iki özelliği veya kuvveti vardır ki, birincisi akıl, diğeri ise vicdandır. Şuur faaliyetlerini idare eden kuvvet akıldır. O düşünüp bilir, delilleri anlar, idrak eder, bilgiler sayesinde hükümlere varır ve hatırlar, işte bu, ruhun akıl yönüdür. "Vicdan'a ise kalp gözü veya basiret yahut sadece kalp de denilir. Merhamet etme, iyilik karşısında hoşnut olma, haksızlık ve kötülük karşısında üzülme gibi deruni ve manevi hislerin kaynağı da ruhun vicdan denilen yönüdür. ${ }^{32} \mathrm{Bu}$ yüzdendir $\mathrm{ki}$, vicdan hüküm verirken maddi menfaat gözetmez. $O$ hak ile batılı birbirinden ayırır, haksızlık, kötülük ve cinayetler karşısında üzüntü duyar. ${ }^{33}$

Peygamberimiz vicdanla ilgili olarak şöyle beyanda bulunur: "Bir (iyilik ve itaat) güzel ahlaktır; ism (günah ve kötülük) de vicdanını tırmalayan, seni rahatsiz, huzursuz eden ve insanlarm muttali olup bilmesini istemediğin şeydir." 34 İşte bu yüzdendir ki, insan zaman zaman aklını ikna edip susturulabilse de onun için en zor olan şey vicdanını susturmasıdır. Zira vicdanın mahalli, akıl değil kalptir; ikna edilmesi de işte bundan ötürü daha güçtür. Bundan dolayı Peygamberimiz vicdan muhasebesi yapılmasını istemiş, insanlara akıl ve vicdan birlikteliğiyle kötülüğü tespit etme yolunu öğretmiştir.

Vicdan, Modern Avrupa felsefesinde, çoğunlukla ya şahsi ya da ahlaki özellik olarak görülmüştür. Bireyin bütünlügü ise, her iki durumda da odak noktasını teşkil eder. Vicdan veya vicdan bağı ahlaki kanaatlerden daha derinlere inmektedir ki, bu yapı, siyasi, ahlaki ve dini konularda aynı şeyleri düşünüp düşünmediğimize bakmaksızın kendimiz dışındakilerle sıkıntılara katlanmaya ve onları desteklemeye, acılarını

31 Nurettin Topçu, İsyan Ahlakı, çev. M. Kök - M. Doğan (İstanbul: Dergâh Yayınları, 2006), 195.

32 Bağçeci, “Vicdan”, 8/234.

33 Bağçeci, “Vicdan”, 8/236.

34 Müslim, "Birr", 14; Ebu İsa Muhammed b. İsa b. Sevre et-Tirmizi, es-Sünen (b.y.: Riyad: Daru'l-Hadara, 1436/2015), "Zühd”, 65. 
paylaşmaya hazır olduğumuzu ifade eder. ${ }^{35}$ Şu halde ahlaki şuur (vicdan) bir fetten diğerine değişmez. Esas olan ahlakın temellerini fetlerin vicdanında sabitleştirmektir. İşte bu ferdi ve sosyal ahlak, fertlere emreden, onları belirli şekilde hareket etmeye zorlayan, şahsi temeyüllerine sınır çizen ve daha ileri gitmelerine engel olan kurallardan oluşmaktadır. ${ }^{36}$ Tam bu noktada, çocukların ve özellikle öğrencilerin vicdanlarına hitap etmeyi başardığımızda hoşgörü öğretiminin temellerini atmış ve inançlar üstü dayanışmayı öğrenmelerine en büyük katkıyı sunmuş oluruz. Dolayısıyla "bu anlayış, bireysel vicdanların dinler tarafından hoşgörüye çizilmiş geleneksel sınırlara meydan okuyan yeni tür bir ahlaki topluluk meydana getirebilecekleri anlamına gelir." ${ }^{\prime 37}$ Bunu başarmanın en kestirme yolu, insanın fitratını bozmadan soyalleştirilmesi ve geliştirilmesidir.

\section{Vicdan Nasıl Gelișir?}

Kültürlerin hepsi öğrenme sonucu oluşmuştur. Eğer kültür sosyolojik açıdan, bir toplumun veya toplum içindeki önemli bir grubun, bütün yaşam tarzını, yani inançları, değerleri, paylaşılan anlamları, rutin pratikleri ve el sanatlarını ifade ediyor ${ }^{38}$ ise -ki öyledir- elbette bütün bunlar bir öğrenme sonucu edinilmekte ve kazanılmaktadır. Hiçbir insan doğuştan din, etnik, kültürel ve benzeri yönlerden kendinden farklı olan insan ve toplumlara karşı vicdansız, önyargılı, hoşgörüsüz ve saygısızlık gibi olumsuz niteliklere sahip değildir. Bu perspektiften bakılınca hoşgörülü, vicdanlı olma kültürünün oluşmasında eğitimin önemi daha iyi kavranabilir. Başka bir deyişle vicdansızlık, merhametsizlik, acımasızlık, hoşgörüsüzlük öğrenilmiş bir davranıştır. ${ }^{39}$ Buna göre

35 Oddbjorn Leirvik, “Hoşgörü, Vicdan ve Dayanışma: Ahlak ve Din Eğitiminde Küreselleşen Kavramlar", Değerler ve Eğitimi, Recep Kaymakcan vd. (İstanbul: Dem Yayınlar1, 2013), 539-544.

36 Emile Durkhim, Meslek Ahlakı, çev. Mehmet Karasan (İstanbul: Milli Eğitim Basımevi, 1986), 6-11.

37 Leirvik, "Hoşgörü, Vicdan ve Dayanışma: Ahlak ve Din Eğitiminde Küreselleşen Kavramlar", 550.

38 Paul Filmer, "Yüksek/Kitle", çev. M. Ali Kirman - Talip Baycar, Temel Sosyolojik Dikotomiler, ed. Chris Jenks (Ankara: Atıf Yayınları, 2014), 470.

39 Recep Kaymakcan, "Bir Değer Olarak Hoşgörü ve Eğitimi", Değerler ve Eğitimi, ed. Recep Kaymakcan vd. (İstanbul: Dem Yayınları, 2013), 521; Hayati Hökelekli, Psikoloji, Eğitim ve Din Yönüyle İnsanî Değerler (İstanbul: Dem Yayınları, 2013), 196. 
çocuklara verilen eğitim ve öğretimin öncelikle tasarlanmasına ve kültürel değerlerin yönlendirmesiyle birçok davranış örüntüsünün oluşuyor olduğuna dikkat etmek gerekmektedir.

İnsan, akıl ve irade sahibi olmasıyla kâinatın merkezî varlığıdır. İnsan çıkarılıp atılmış olsa kâinat anlamsız kalır. Bu bakımdan insanı çok iyi anlamak, tanımak gerekmektedir. Başka bir ifadeyle insana tek yanlı olarak bakmamak gerekmektedir. Tek yanlı insan anlayışları, insanı sırf düşünce ve ruh olarak görmekten ya da onu sadece beden ve madde olarak kabul etmekten ibarettir. Bu yaklaşım, insanın bir yanını ihmal ettiği, görmezlikten geldiği için, insanı tam olarak tanıyamadığı gibi tanıtmaktan da uzak bulunmaktadır. Esas olan ise insanı tek yanlı değil, bütün olarak görmek ve anlamaktır. Bu, insanı maddi yapısının yanısıra tutum ve davranışlarıyla, düşünce ve tavırlarıyla kısaca bütün yapıp etmeleriyle tanımak ve tespit etmekle mümkündür; yani insan bir yönüyle düşünce ve ruhtan oluşurken diğer yönüyle beden ve maddeden oluşan bir bütündür. ${ }^{40}$ Şüphesiz insan beden ve madde, düşünce ve ruh olarak toplumsal bir varlıktır. Toplumsal bir varlık olarak insan, yapmayı kararlaştırdığ1 eylemleri ile toplum içinde ilişkiler kurar ve bunun sonucunda eserler meydana getirir. ${ }^{41}$ Çünkü özel bir varlık olarak insan, bir ailede veya çevre (grup) içinde, genelde ise bir toplum içinde varlığını sürdürür. Niteliklerini kazandığı, edindiği yer içine doğduğu grup ve çevresidir; merhameti ve merhametsizliği, vicdanlı olmayı ve vicdansızlı̆̆ı, kavgayı, saldırganlığı, hoşgörüsüzlüğü, şiddeti, terör yanlısı olmayı veya empati yapabilmeyi, en yakınından başlayarak çevresinden öğrenir. Kişi, kendi tercih ve eğilimlerine istinaden bu nitelikleri belirler, ayıklar ve seçerek benimser. ${ }^{42}$

Doğuştan getirdiğimiz vicdan, öyle bir mekanizmadır ki, o çevremiz, yaşantılarımız ile gelişir ya da geriler. Diğer bir deyiş̧le vicdan denilen mekanizma, insanın duygu ve düşüncelerini, bunlardaki maksat

40 Asım Yapıcı, İslam'da Tövbe ve Dini Yaşayıştaki Önemi (İstanbul: Beyan Yayınları, 1997), 72.

41 Yılmaz Özakpınar, İnsan Düşüncesinin Boyutları (İstanbul: Ötüken Yayınları, 2002), 47.

42 İsmail Doğan, Sosyoloji (İstanbul: Sistem Yayınları, 1998), 90; Nedim Öz, "İlahiyat Fakültesi Öğrencilerinin Din/İslam ve Şiddet İlişkisini Algılayışı (Kilis 7 Aralık Üniversitesi Örneği), Kilis 7 Aralı Üniversitesi İlahiyat Fakültesi Dergisi 2/3 (Aralık 2015), 162. 


\section{8 | N. ÖZ / Vicdanlı Nesilden Vicdanlı Topluma}

ve niyetleri dikkatle izler, hatır, gönül, dost-ahbap yakın demeden yargılar, sorumluluğu takdir, sorumsuzluğu tekdir eden uyanık bir hâkimdir. Vicdan, ahlaki değer duygusundan kaynaklanan ahlak kurallarının yaptırım gücüdür. ${ }^{43} \mathrm{O}$, bu noktaya nasıl gelmekte ve getirilmektedir? Tam tersi bir durum söz konusu ise, bu nasıl ve ne şekilde olmaktadır? Her şeyden önce, bu bir eğitim ve sosyalleşme sürecidir. Vicdanı inşa edecek olan dini-ahlaki normlar sosyal normların bir çeşidini teşkil eder ve insanın, biyolojik bir varlıktan sosyal bir varlık haline gelmesi denilen sosyalleşmeyle o, toplumunun bir üyesi haline gelir. ${ }^{44}$ Artık o kişiden toplumsal değerler ve normlara uygun davranan, doğru kararlar veren ve vicdani gelişimine olumlu katkılar sunan bir birey olması beklenir. Ancak sosyalleşme sürecinde müspet yönde gelişimi bakımından vicdanın köreltilmemesi de son derece önemlidir. Zira bedenin hastalığa yakalanmayıp salim kalabilmesi için suya, gıdaya ihtiyacı olduğu gibi, vicdanın da sağlam kalması, bozulup ölmemesi için inanmaya ve kirletilmemeye ihtiyacı vardır. Zira bâtıl inanışların, kötü örf ve adetlerin, bozuk çevre ve aşırılıkların vicdan üzerinde menfi tesirleri söz konusudur. Bu yüzden iyilik ve fazilet ortamında gelişmemiş vicdan, inkâr ve kötülükler karşısında üzüntü duymaz. Bunlar da vicdanı zayıflatır, köreltir ve nihayet onun büsbütün ölümüne neden olur. ${ }^{45}$

Şu ayet bu hususlara delalet eder: "Hayır, hayır onların kazandıkları günahlar, kalplerini paslandırıp yenmiştir." $46 \mathrm{Bu}$ gün içinde bulunduğumuz yüzyılda kalpleri paslanmış, vicdan denilen en temel gücünü yitirmiş olan insan, robotlara duygu kazandırmayı ve körelen vicdanları nasıl harekete geçirebileceğini tartışıyor; ebeveynine zarar veren çocukları, aynı yastığa baş koyanların işlediği cinayetleri, dünyadaki kaynakları sadece kendisi için isteyenleri, bebek katillerini; modern köle pazarlarını, gücü olanın haklılığını ve "öteki" olarak kabul edilenin yaşama hakkının olmadığını; ihmal, istismar, ihanetler ve cinayetleri konuşuyor ise, durum, gelecek açısından vahim olsa da bütünüyle ümitsiz değildir. Bu açıdan ailenin ve toplumsal atmosferin öğretmenliğini, karakterin

43 İlhami Güler, İman Ahlak İlişkisi (Ankara: Ankara Okulu Yayınları, 2010), 120.

44 Erol Güngör, Değerler Psikolojisi (Amsterdam: Hollanda Türk Akademisyenler Birliği Vakfı Yayınları, 1993), 15.

45 Bağçeci, “Vicdan”, 8/234.

46 el-Mutaffifin 83/14. 
oluşmasındaki etkisini hiçbir şekilde unutmamak gerekir. O yüzden burada, vicdanın olumlu ya da olumsuz noktadaki gelişimi, aile ve çevre ekseninde ele alınarak vicdan sahibi nesiller yetiştirmek suretiyle vicdanlı bir toplum oluşturulabileceği meselesi analiz edilmektedir.

\section{Vicdan Gelişiminde Ailenin Önemi}

Çocukta, vicdanın gelişmesi ya da körelmesi aile ortamında şekillenmeye başlar. Başta ailesi olmakla birlikte çocuğun Durkheim'in de belirttiği gibi, yakın çevresindeki nesnelere kolaylık ve sadakatle bağlandığı, ağlayanla ağladığı, gülenle güldüğü, çevresinde olan biten her şeyi taklit ettiği ${ }^{47}$ ve acıma potansiyeline sahip olduğu bilinmektedir. Dolayısıyla çocuktaki vicdan duygusunun dengelemesinde ailedeki sevgi duygusuna olan ihtiyacın yaşamsal bir önemi vardır. Vicdanlı ve merhametli bir nesil yetiştirilebilmesi için ailenin, çocuklara sevgiyi, hürmeti, merhameti, nezaketi, güveni, sadakati vb. kazandırması gerekmektedir. Tersi bir tutum, tavır ve süreç ise vicdansız, merhametsiz nesillerin yetiştirilmesiyle sonuçlanacaktır. Boş bir levhaya benzeyen çocuklara, ne verilir ve işlenirse elbette onun karşılığı alınacaktır. Başka bir ifadeyle aileden başlayan bir çevre içinde çocuk pek çok şeyleri görür, duyar, öğrenir ve bunlardan bilinçli-bilinçsiz etkilenerek ${ }^{48}$ vidanlı ya da vicdansiz hale gelebilir.

Aile, sosyolojik manada toplumsal normların aktarılması, toplumsal rollerin edinilmesi ve sosyal kimliğin oluşmasında ${ }^{49}$ toplum ile birey arasında önemli işlevlere sahiptir. Diğer bir deyişle “insan içinde doğduğu ailenin ve grubun kültürünü maddi ve manevi boyutlarıla öğrenmekte ve benimsemektedir. $\mathrm{Bu}$ da toplum açısından kültürün kuşaklar arasında aktarılmasını ve süreklilik kazanmasını

47 Emile Durkheim, Ahlak Eğitimi, çev. Oğuz Adanır (İstanbul: Say Yayınları, 2016), 250251.

48 Kerim Yavuz, Çocukta Dini Duygu ve Düşüncenin Gelişmesi (Ankara: DİB Yayınları, 1983), 26.

49 Sinan Yılmaz, Türkiye'de Ailenin Dönüşümü (Ankara: Divan Kitap, 2012), 22; Bedir Sıla, "Uyumdan Çatışmaya: Bir Ara Kurum Olarak Ailenin Sosyalleşme Sürecindeki Rolü", Aile Kurumuna Farklı Bakışlar, ed. Özlem Altunsu Sönmez - Gamze Aksan (Konya: Çizgi Kitabevi, 2019), 42. 
sağlamaktadır". ${ }^{50}$ Küçük çocuklar, özellikle evde gördükleri davranışları ve çevrelerinde olup biten şeyleri taklit ederler. Onlar iyi bir alıcı, yüksek bir taklit gücüne sahip olduğu için çocuk eğitimine, daha doğar doğmaz başlamak gerekmektedir. "Ağaç yaş iken eğilir" atasözümüz, bunu veciz bir ifade ile teyit etmektedir. Bu nedenle bireyin fiziksel, zihinsel, ahlaki gelişim süreçlerinde eğitici konumundaki herkes, özellikle anne-baba ve öğretmenler çok önemlidir. Çocuğun zihinsel ve ahlaki gelişimini öteleyerek fiziksel gelişimine odaklanmak, farkında olunsun veya olunmasın, ona yapılabilecek en büyük kötülüklerdendir. Örneğin toplumsallığın ilk gerçekleştiği yer olan ailede ${ }^{51}$ izlenilen mafya dizileri, çocukların vicdan ve merhamet duygularını törpülemekte, aynı çocuklar okulda ve sokakta da dizi karakterleri gibi davranmaktadır. Başka bir deyişle eğer çocuklar, güçlü olanlar zayıf olanları ezer şeklindeki yanlış bir anlayışla büyüyor ise, şefkat, merhamet, acıma duyguları zayıf kalmakta ve toplumsal kurum olan ailenin kültür aktarma işlevini tam yerine getirmediği görülmektedir. ${ }^{52}$ Nitekim günümüzde artık geçmişin masalları ya da öykülerini anlatan aile büyükleri yerine "elektronik bir $\mathrm{dev}^{\prime \prime 53}$ olan televizyon, çocukları kendine özgü öyküleriyle, ninnileriyle, masallarıla yetiştirmektedir. O yüzden son zamanlarda sokaklarda insanlar birbirlerini eziyor veya eziyet ediyorken, diğer yığınlar da onları seyretmekle yetiniyorsa, sebebini istenen seviyede işlev görmeyen aile ve sosyal çevrede ${ }^{54}$ aramak gerekir.

$\mathrm{Bu}$ durumlara düşmemek için ahlak ve erdem sahibi nesiller inşa etmek gerekmektedir. Ahlak ile erdem ise vicdan sahibi kişilerde olur. İnsanda bir çekirdek ve değer olarak mevcut olan vicdan, çocukluktan

50 Hasan Coşkun, "Modernleşme Sürecinde Aile'de Kimlik", Kadın ve Aile Üzerine Araştırmalar Dini, Tarihi, Sosyolojik ve Psikolojik Analizler, ed. Emine Öğ̈̈k (Ankara: İlahiyat Yayınları, 2018), 261.

51 Kenan Çağan, "Ailenin İşlevleri”, Aile Sosyolojisi, ed. Kadir Canatan - Ergün Yıldırım (İstanbul: Açılımkitap, 2013), 83.

52 Özge Zeybekoğlu Dündar, “Değişen ve Değiş(e)meyen Yönleriyle Aile: Yapısı, Türleri, İşlevleri", Değişen Toplumda Değişen Aile Sosyolojik Tartışmalar, ed. Nurşen Adak (Ankara: Siyasal Kitabevi, 2018), 58.

53 Hasan H. Taylan, Televizyonla Yetişmek: Televizyon Şiddetinin Etkileri Üzerine Bir Araştırma (Konya: Çizgi Yayınları, 2011), 40.

54 Özcan Güngör, Sosyalleşme ve Din", Din Sosyolojisi, ed. Özcan Güngör - Rıdvan Şimşek (İstanbul: Lisans Yayınları, 2020), 506-507. 
itibaren anne-babalar ve öğretmenlerin çabası ile filizlenerek geliştirilir. Yapılan araştırmalar, anne-baba davranışlarının en önemli etkiyi çocuk üzerinde yaptığını, müspet davranışların çocuğa doğrudan yansıdığını ortaya koymuştur. ${ }^{55}$ Dolayısıyla ana-baba ve büyüklere saygı, itaat, sıla-i rahim, yaşlılara, yoksullara, hastalara, bakıma muhtaç engellilere, dul ve yetimlere, kimsesizlere, yolda kalmışlara yardım, hayvanlara karşı şefkatle muamele, tabiat ve çevreyi hor kullanmama gibi konularda ortaya konulan pek çok dini emir ve tavsiye, İslam'ın rahmet ve merhamet, vicdân ve hoşgörü ahlakının temel parçalarını meydana getiren ilkeler çocuklara ebeveynlerince anlatılmalı, yaşayarak gösterilmelidir. ${ }^{56}$ Zira insanı insan yapan merhamet, vicdan ve acıma duygularının iyi gelişmesi ile diğer bütün güzel hasletler de pekişmektedir. Bu da her yönüyle çocuğa verilecek olan bakım ve eğitim ile başlar. "Çocuğun bulunduğu ortamdaki bireylerin birbirlerine karşı sevgi dolu, saygıll, yardımsever ve anlayışlı olması çocuklarda vicdan, merhamet duygularını geliştirir. Çocuklar olumsuzluklardan ne kadar uzak kalır, güzel örnekleri görerek büyürse sevgi ve merhamet de onların hayatında o derece yer bulur." 57 Örneğin bir bebek veya çocuk annebabadan sadece konuşmayı, yürümeyi öğrenmez, hangi olay ve olgulara ne tür bir tepki vereceğini de öğrenir. Söz gelimi anne bir karınca veya uğur böceği gördüğünde 'ne kadar da güzelsin. Seni çiçeklerin arasina koyalım da kimse üstüne basıp canını acıtmasın' şeklinde şefkati, merhameti, vicdanı içinde barındıran bir davranış sergiliyorsa, elbette çocuk bunu hemen alıp kopyalar ve uygular. Uzmanlar ${ }^{58}$ minikler tarafından ebeveynlerin sadece davranışları değil, onların vicdanlarını da kopyaladıkları, taklit ettikleri konusunda hemfikirdir. Böylece çocuk, yakın çevresindeki model edindiği kimselerden, taklit ve özdeşleşme ile ahlaki güzellikleri öğrenir.

55 M. Emin Ay, Çocuklarımıza Allah'ı Nasıl Anlatalım (İstanbul: Timaş Yayınları, 1998), 124.

56 Ferhat Koca, "Rahmet ve Merhamet Çağrısı Olarak İslam”, Hz. Peygamber ve Merhamet Eğitimi (Ankara: DİB Yayınları, 2012), 72.

57 Havva Sula, "Rahmet, İsteneni Değil İhtiyaç Duyulanı Vermektir", Hz. Peygamber ve Merhamet Ĕ̆itimi (Ankara: DİB Yayınları, 2012), 127.

58 Bk. Yurdagül Mehmedoğlu, Okul öncesi Çocuklarda Dinî Duygunun Gelişimi ve Eğitimi (Ankara: TDV Yayınları, 2005), 21-25; Doğan Cüceloğlu, İnsan ve Davranışı (İstanbul: Remzi Kitabevi, 2018), 331-332. 
İnsan olmak, aslında merhamet ve vicdan sahibi olabilmektir. İçsel bir güç olarak vicdan, kişinin yaşadıklarına bağlı olarak zamanla gelişir veya körelir. Vicdanın temelinde sevgi ile inanç vardır. İnsan kanundan her zaman kaçıp kurtulabilir; kaçamayacağı yegâne varlık ancak Mutlak Varlıktır. Günümüzde de hukuk kuralları insanları müspet yönlere yöneltmeye yetmemektedir. Eğer yetseydi, kanunlar değişmezdi. Bu sebeple bir kontrole ihtiyaç vardır. Bunun yolu, insanın içten, yürekten, samimiyetle bir kayıt ve kontrolü yapabilmesidir. Bu iç kontrol ancak insanın Aşkın varlığa bağlılığıyla, bu konuda kendi kendisine emir verip o emri icra etmesiyle mümkündür. Allah'ı unutan veya yok sayanlar vahşi birer saldırgan veya insan yiyen birer canavar kesilebiliyor. Allah yoksa beni belirleyecek değerler de olmaz. İnsan kendi kendini yaratma sevdasına düşerse bencil, egoist, kendini beğenmiş bir varlık olur. ${ }^{59}$ Başka bir ifadeyle değere inanan insan onun müeyyidesinden de çekinir. Bu çekinme, kişiyi ölçülü davranmaya sevk eder. Mesela kul hakkına inanan kişi, herhangi bir şekilde o fiili olumsuz olarak yapmamaya, kul hakkı yememeye çalışır. Çünkü kul hakkı yiyen kimsenin mutlak varlık katında, hakkını yediği kişilerle helalleşmedikçe affa uğramayacağını, Allah'ın rahmetinden, sevgisinden mahrum kalacağını bilir, bundan çekinir. Kültürümüzdeki ‘Kul hakkı yiyenin olmayacağı', ‘Tüyü bitmedik yetimlerin hakkını yemiş olacağı' inanc1, bunda etkili olur. Sevgiyi kaybetmek korkusu imanı, iman da doğru eylemi kuvvetlendirir. ${ }^{60}$ Bütün bunları çocuklara verecek ve kazandıracak olanlar başta aile, öğretmenler, akrabalar, komşular, dedeler, neneler, ablalar, ağabeyler ve bütün büyükler; diziler, filmler, oyunlar, belgeseller, kitaplar, kıssalar, hikâyeler, romanlar, gazete ve dergiler; görsel ve işitsel yollarla bütün bir toplum, toplumsal kurum ve kuruluşlardır. Bu konuda herkes sorumluluk sahibidir.

Öğrencilerin ya da çocukların aile ile okul arasındaki iletişimi ise karşılıklıdır. Öğrenciler okulda vicdan, merhamet, hoşgörü ve diğerlerine sayg1 konusunda öğrendiklerini ailesine, ailesinde öğrendiklerini de okula taşıyacaktır. Buna göre çevrede, okulda ve arkadaş grubu arasındaki hoşgörü veya hoşgörüsüzlük, vicdansızlık vb. düşünceler ve

59 Süleyman Hayri Bolay, “Aşkın Değerler Buhranı”, Değerler ve Eğitimi, ed. Recep Kaymakcan vd. (İstanbul: Dem Yayınları, 2013), 66-67.

60 Bolay, “Aşkın Değerler Buhranı”, 63. 
uygulamalar büyük oranda kaynağını aile içerisindeki ilişkilerden, bu husustaki farkındalık düzeylerinden sağlamaktadır. Ö̈rneğin aile üyelerinin birbirine yönelik merhamet yüklü ilişkilerinin yanı sıra yoksullara, hastalara, yaşlılara yapılan yardım faaliyetlerinin çocuklara izletilmesi, şiddet, çatışma gibi ortam, oyun ve haberlerden uzak tutulması vicdan kazanımında önemli adımlardır. Dolayısıyla kurumlar arasındaki karşılıklı ilişkiler ve eşgüdüm, vicdan ve hoşgörü eğitiminin önemli basamaklarından birini oluşturmaktadır.61 Buradaki organizasyon ve koordinasyonun uyumlu, birbirini destekleyici, pekiştirici olması, çocukların vicdan, merhamet ve hoşgörü sahibi olmasında çarpan etkisi yaratacaktır.

\section{Vicdan Gelişiminde Çevrenin Önemi}

Çevre kavramı, insan ya da bir başka canlının yaşamı boyunca içinde ilişkilerini sürdürdüğü dış ortam;;2 merkez dişında kalan alanlar anlamına geldiği gibi, insanı saran tabii şartlar manasını da taşımaktadır. ${ }^{63}$ Bir başka ifadeyle içinde yaşanılan ortama çevre denilmektedir. Bu anlamda bütün canlıların bir çevresinin olduğu söylenebilir. Ancak içinde bulunduğu bütün varlıklarla yakından uzağa genel bir bilgi anlamında çevre olgusu insana özgüdür. Çünkü diğer canlıların en yakınındaki pek çok şey kendisini ilgilendirmemekte, dolayısıyla bir çevre unsuru olmamaktadır. Bu haliyle çevre sosyal varlığın önemli boyutlarından birisidir. ${ }^{64}$ Dolayısıyla insanın içinde yaşadığ1 toplumun bir sosyal münasebetler ve sosyal teşkilatlar ağ165 olduğuna bakılırsa, fertlerin içinde yaşadığı toplumda, o toplumu oluşturan bireyler ile hem sosyalleşme hem de sosyalleştirme açısından doğrudan ya da dolaylı bir ilişki içinde olduğu görülecektir. Bu süreç içerisinde, günümüzde sadece çocukların değil, gençlerin ve yetişkinlerin de olumlu veya olumsuz yönde etkilendiği çevresel faktörlerin başında okul, arkadaş gurupları, komşular, akrabalar, kitle iletişim araçları diye

61 Kaymakcan, "Bir Değer Olarak Hoşgörü ve Eğitimi", 523.

62 Ömer Demir - Mustafa Acar, Sosyal Bilimler Sözlüğü (İstanbul: Ağaç Yayınları, 1992), "Çevre", 73.

63 Mustafa E. Erkal vd., Ansiklopedik Sosyoloji Sözlü̆ğ̈̈ (İstanbul: Der Yayınları, 1997), "Çevre", 77.

64 Mustafa Aydın, Güncel Kültürel Kavramlar (İstanbul: Açılım Kitap, 2013 ), 87.

65 Ünver Günay, Din Sosyolojisi (İstanbul: İnsan Yayınları, 2014), 19. 
tabir edilen yazılı ve sözlü basın, dergi, gazete, kitap, sinema, tiyatro, radyo, televizyon, bilgisayar, internet, $C D$ ve DVD gibi ortamlar geniş bir yelpaze oluşturmaktadır.

Şüphe yok ki bir insanın davranışları sadece güdülere bağlı olarak meydana gelmemekte, sosyal çevre, kültürel ortam gibi pek çok faktör de bu konuda etkisini göstermektedir. ${ }^{66}$ Bireyin doğuştan getirdiği kabiliyet ve istidatlarına ilave olarak sosyal çevresinde hazır vaziyette bulduğu inançlar, kültürel değerler, örf ve adetler vardır $\mathrm{ki}$, bunlar, onun şahsiyetinin gelişmesinde, olumlu veya olumsuz biçimde, mühim bir rol oynadığ1 kabul edilmektedir. Yani sosyal çevrenin, kültürel alışkanlıkların ve bu arada çevresindeki fertlere olumsuz bir model teşkil eden kişilerin ${ }^{67}$ gençleri etkileyerek çeşitli günahlara, vicdansızlık ve merhametsizliklere hatta inkâra dahi yönlendirdiği bilinmektedir. Bu yüzden akran ${ }^{68}$ ve arkadaş çevresi, çocuk eğitiminde, sosyalleşmede önemli bir yer tutar. Kötü arkadaşlar onun için olumsuz bir sosyal çevredir. Çünkü kötü arkadaş grupları kendilerine yakın olan veya kendi bünyesinde bulunan kişileri günah ya da kötü fiilleri yapma konusunda şu veya bu şekilde etkileyebilmektedir. Esasen fertler dâhil olduğu grubun normlarına ister istemez uymak durumundadırlar. ${ }^{69}$ Arkadaşlık olgusu ve bu konudaki atasözlerimiz de oldukça ilgi çekicidir. Nitekim, "kişi akranından belli olur", "arkadaşını söyle sana kim olduğunu söyleyeyim"70 gibi atasözlerimizde arkadaş grubunun, birey üzerinde ne kadar büyük bir tesiri olduğu kendini göstermektedir. Çünkü insan bireyselliğinin yanında sosyal bir varlıktır, çevresi ile çeşitli şekillerde iletişime ve etkileşime girmek durumundadır. Bu süreçte arkadaş çevresinden olumlu veya olumsuz anlamda etkilenmektedir. Bundan dolayı öncelikle aile ve diğer eğitici aktörlerin, özellikle temel eğitim aşamasındaki çocuğun fiziki ve sosyal çevresini oluşturan, kitle iletişim

66 Muzaffer Şerif, Sosyal Kurallarm Psikolojisi (İstanbul: Alan Yayıncllık, 1985), 30-40.

67 Yapıcı, İslam'da Tövbe ve Dini Yaşayıştaki Önemi, 42.

68 Mustafa Köylü - Bayramali Nazıroğlu, "İlköğretimde Din Eğitimi", Din Eğitimi, ed. Mustafa Köylü - Nurullah Altaş (İstanbul: Ensar Neşriyat, 2014), 178.

69 Şerif, Sosyal Kuralların Psikolojisi, 30-40.

70 Milli Kütüphane Başkanlığı, Türk Atasözleri ve Deyimleri (İstanbul: Milli Eğitim Bakanlığ1 Yayınları, 1997), 1/30. 
araçları ve arkadaş grubunu (çevresini) daha dikkatli bir biçimde takip ve kontrol etmesi gerekmektedir. ${ }^{71}$

Televizyon ve internet oyunlarının, özellikle çocuklarla gençler üzerinde şiddet, saldırganlık duygularının ve davranışlarının oluşmasında; ahlaki değerler ve cinsellik gibi konularda olumsuz etkilere sahip olduğu görülmektedir. ${ }^{72} 1950$ 'li yıllardan beri yapılan araştırmalar, televizyonun, çocukları daha saldırgan, kavgacı yaptı̆̆ını ve şiddete yönelmelerine neden olduğunu göstermektedir. Bu konuda ebeveynin de gerekli ve yeterli özeni göstermemesi, izlenen televizyon programlarının yıkıcı ve tahrip edici yöndeki etkisini daha çok artırmaktadır. Örneğin, "haberler, şovlar, filmler, diziler hatta çizgi filmler bile hep saldırganlık, şiddet, cinsel istismar, hırsızlık, gasp ve çalışmadan köşe dönme fikrini işlemekte, sonuçta bu tür yayınlar, başta öğrenmenin en ideal çağında olan çocuk ve ergenler olmak üzere, tüm toplum üyelerini olumsuz yönde etkilemektedir."73 Bunlar içerisinde, şiddet içerikli olmayan internet oyunu neredeyse yok gibidir. İşte yeni nesiller, bu oyunları oynamak suretiyle başta zamanlarını boşa geçirmekte, şiddete maruz kalarak ona eğilimi teşvik edilmekte, kişilik ve karakterini bu şartlarda oluşturmaya çalışmaktadır.

Gazete, dergi ve kitaplar da çocukların dini ve ahlaki tutum ve davranışlarını, vicdan, merhamet, acıma duygularını olumlu ya da olumsuz yönde etkileyen faktörlerden birisidir. Önemli bir uyaran olarak okunanlar, zihinsel, duygusal ve sosyal gelişimi itibariyle çocuğu etkilemektedir. Çocuk ebeveynini nasıl model alıyorsa, okuduğu gazete, dergi ve kitaptaki kahramanları da model olarak almakta, oradaki olaylardan etkilenmektedir. Buralarda benimsediği kahramanlara benzemek ve aynı özelliklere sahip olmaya çalışmak çocuklar için cazip olan bir durumdur. Dolayısıyla sanat değeri taşımayan, eğiticilik yönü olmayan, olumlu davranış değişikliği sağlamayan dergi, gazete ve kitaplar, okuma zevki vermediği gibi, aksine çocukları şiddete,

71 Mustafa Köylü, “Ailede Din Eğitimi”, Din Eğitimi, ed. Mustafa Köylü - Nurullah Altaş (İstanbul: Ensar Neşriyat, 2014), 341.

72 Taylan, Televizyonla Yetişmek, 1.

73 Köylü, “Ailede Din Eğitimi”, 339-341; Taylan, Televizyonla Yetişmek, 1-7. 
386 | N. ÖZ / Vicdanlı Nesilden Vicdanlı Topluma

vicdansızlığa yönelttikleri için onları çocuklardan uzak tutmak gerekmektedir. ${ }^{74}$

Sadece başarıya odaklı, sahip olmak dürtüleriyle yetiştirilip sorumluluk verilmeyen yeni nesiller, fitratlarına ve vicdanlarına uygun bir şekilde gelişemezler. Herhangi bir şeyi infak etmeyi ve merhametli olmayı kendilerine model olup öğret(e)mediğimiz, akranlarıyla yarıştırarak rekabet duygularını körüklediğimiz, gündelik uygulamalarla egolarını, haz alma ve bencillik ${ }^{75}$ duygularını pekiştirdiğimiz çocuklar, vicdanlarını geliştiremezler. Tevazu sahibi olamazlar. ${ }^{76}$ Acaba, bu gençler özür dilemenin eksiklik, teşekkür etmenin eziklik olduğunu nereden, nasıl öğrendiler? Akran zorbalığı ile küçük yaşlarda tanışan; bir canı yakmayı, incitmeyi ve yok etmeyi, insanı dışlamayı normal görür hale gelen yavrularımız pişmanlık duyabilmeyi, incittiği biri için üzülebilmeyi ve gerektiğinde gözyaşı dökmeyi yeterince öğrenemez. Çocukların vicdanları, böyle bir aile, okul ve toplum ortamı, eğitim ikliminde canlı, güçlü ve etkin olamaz. Zira vicdan, olumsuzluklarla birlikte sürekli susturulursa konuşamaz; o daima ikna ve itmam edilmeli ve aldatılmamalıdır. Örneğin, 'kardeşine vurman doğru değil' cümlesinden sonra, 'başka türlü nasıl davranabiliriz?' diye kendisine soru sorulup, sonrasında doğru ve iyi olanı belirterek çocuğa rehberlik yapılmalıdır. Aslında kendisiyle doğru iletişim ${ }^{77}$ kurulduğunda hislerini ifade edecek ve 'evet, öyle yapmayabilirdim' diyerek vicdanın sesine kulak verecektir. $\mathrm{Bu}$ yüzden doğallıktan uzak tavır ve davranışlardan kaçınarak doğruyu ortaya koymak, çocukların vicdanına müsbet yönde tesir edecektir.

Vicdanın körelme süreci, onun kötüye ve kötülüğe alıştırıldı̆̆ 1 vakitte başlamaktadır. Vicdan kötüye ve kötülüğe, çocukların önce sözle sonra görüntülerle alıştırılmasıyla ilk yarayı almış olur. Artık bundan sonraki süreçte videolarda, bilgisayar oyunlarında şiddet ve eziyet kol gezer; vahşice işlenen cinayetler, yaralamak, parçalamak ve öldürmek gibi nicesi alabildiğine normalleşir. Burada oyunun ve de yaşamın ilk

74 Köylü, “Ailede Din Eğitimi”, 341.

75 Mustafa Çağrıcı, "Ahlaki Müeyyide", İslam Ahlakl, ed. Muhammed Şevki Aydın Ahmed Hadi Adanalı (İstanbul: DİB Yayınları, 2014), 180.

76 Muhammed Şevki Aydın, Eğitim Ahlakı (Ankara: DİB Yayınları, 2020), 60.

77 Ahmet Özcan, "İletişimin Önemi”, Medya ve İletişim, ed. Hüseyin Özhazar (İstanbul: Anadolu Eğitim ve Davet Gönüllüleri Platformu, 2012), 21. 
kuralı vicdansızlık üzerine kurulmuştur. Artık çocuk, her şeyi bir oyun kahramanı çerçevesinde değerlendirerek komik bulur, kanlar içerisinde acı ile kıvranan zavallı adamı göremez olur. Çünkü gerçeklik algısı bozulmuştur. ${ }^{78}$ Bir süre sonra bozulan gerçeklik algısıyla savaş mağduru çocuğun inlemelerini ve yalvarmalarını da kayda değer, merhamet edilesi bulmayacaktır. Çocuğun gerçeklik algısı kaybolduğu için, normal durumlarda vicdanı harekete geçiren yaralanma, kan, ölüm vb. sıradanlaşması karşısında harekete geçmemekte, hassas bir terazi olan vicdan bunu tartamaz hâle gelmektedir. Böyle bir kültürel ortam ve çevrede yetişen çocuk, yaşadığı toplumda doğru bir rol üstlenememediğ $i$ gibi, sorumluluklarını idrak edip yerine getiremez. Aslında bunu başardığımızda vicdanlı nesiller ve onların vücuda getirdiği vicdanlı toplum tezahür etmiş olacaktır.

Toplumdaki 'sahiplik duygusu', vicdana en çok zararı veren unsurlardandır. Küçük yaşlardan itibaren her şeye sahip olan çocukların, benim olsun, çok olsun, daha fazla kazanmak için okumak lazım gibi anlayışlarla sahiplik duygusu kabarmakta ve giderek acımasız hale gelmektedir. Aynı şekilde hızlı ve aceleci yaşamak da vicdana zarar vermektedir. ${ }^{79}$ Zira acelecilik, telaş, hız ve haza odaklı yaşamak, hayatı eksiltir ve isanın içine bakabilmesine, hayatla konuşup vicdanın sesiyle buluşabilmesine engel olmaktadır. Vicdanın sesini dinleyebilmek için yavaşlamak, sakinleşmek gerekmektedir.

Toplumun üyeleri rutin uygulamalarla birçok iyi davranışı kendiliğinden öğrenip, ahlaki ve vicdani karakter geliştirilebilmelidir. Örneğin başta komşular, aileler, öğretmenler, diğer yetişkinler yardımlaşır, çocuklarla birbirlerine yemek, hediye vb. göndermesi durumunda bu hassasiyeti, karşılıklı yardımlaşmayı çocuklar yaşayarak öğrenir, sonraki zamanlarda bu yaşanmış erdemi kuşaktan kuşağa aktararak sürdürürler. Tıpkı bunun gibi, günümüzde sadece çocukların değil, gençlerin, yetişkinlerin de olumlu yönde etkilendiği akraba, komşu ve dostların hediyeleşmesi, ziyaretleşmeleri, hasta, yetimhane ve huzurevi ziyaretleri, fakirlere yapılan yardım organizasyonları, mezarlık

78 Bk. Feriha Baymur, Genel Psikoloji (İstanbul: İnkılâp Kitabevi, 1985), 132; Sayar - Dinç, Psikolojiye Giriş, 34.

79 Bk. Kemal Sayar, "Hangi Terapi? Çağımızda Benliğin Dönüşümü”, Kültür ve Ruh Sağ̆lı̆̆l, çev. Sabir Yücesoy (İstanbul: Metis Yayınları, 2012), 105-106. 
ziyaretleri yapılarak da vicdan gelişimi desteklenip pekiştirilebilir. Yine, eskiden büyüklerimizin çiçeklerle, ağaçlarla, hayvanlarla konuştuğu, onlara farklı isimler taktıkları gibi uygulamalar yapılabilir. O dönemde bunu anlamakta zorlanan ve tebessümle karşılayan bizler, bütün bir varlıkla, eşya ya da hayvanla bütünleşmenin faydalı olduğunu geç de olsa kavramış bulunmaktayız. Biliyoruz ki vicdanlı ebeveyn ya da eğiticiler rehberliğinde evcil hayvan bakımı vb. çocukların masum vicdanlarında ${ }^{80}$ şefkat ve merhamet tohumunu yeşertecek önemli aşamalardan biri olacaktır. Örneğin, 'ne kadar da küçük, masum değil mi?', 'karnını doyuralım, biz vermezsek aç kalır', 'üşümüş, onu sıcak bir yere koyalım mı?', 'o bize emanet. İlacını verelim de çabuk iyileşsin' gibi replik ve yönlendirmelerin bu sürece çok önemli katkılar sunacağı muhakkaktır.

Çocuklara, kendi öz ahlâkî otoritesi olan ${ }^{81}$ vicdanın önemini anlatabilmek için masallarla hikâyeler etkili, öğretici yollardan biridir. Söz konusu hikâyeler, masalları okuyarak ya da dinleyerek olumlu bir vicdan gelişimi elde edilebilir. Nihayet başta aile olmak üzere okul, toplum ortamı ve eğitim ikliminde sevgi-saygıyı, empati yapabilmeyi, güven duymayı, mazluma, ihtiyaç sahibine yardım ederek cömertliği, farklı inançtan olanlara hoşgörüyü, adalet, sorumluluk duygusu ve bazı becerileri, model olarak, yeni nesillere kazandırabilmeliyiz ki vicdani gelişimlerini tamamlayabilsinler. Toplum olarak bunu başarırsak biri diğerine, eşler birbirine, komşu komşuya, amir memura velhasıl bütün insanlar birbirlerine karşı; hatta hayvanlara, bitkilere ve bütün mahlûkata karşı vicdan, merhamet, acıma duygusu ve empatiyle yaklaşmak suretiyle vicdanlı bir toplumu, dünyayı inşa etmek mümkündür. $\mathrm{O}$ zaman yaralama, zulüm, şiddet, cinayet, öldürme gibi barbarlıklar büyük oranda ortadan kalkar, bunların yerine vidan, merhamet hâkim olur. Dolayısıyla bu noktadan itibaren merhamet, şefkat, hoşgörü, acıma duygusu ve vicdan sahibi insanların temayüz ettikleri özellikleri ifade etmemiz gerekir. Şöyle ki bu hasletler; insana, hasmının hata ve kusurlarını bağışlatır, düşmanlığı dostluğa dönüştürür. Vicdanında acıma duygusu pekişmiş bir insan; bencillikten, kinden ve nefretten uzak durur. Ahlakı güzelleşir, fazileti artar. Acıma duygusu zayıf olan insan ise katı yürekli ve davranış olarak da kabadır. Hastaya, yoksula, düşküne,

80 Hökelekli, Psikoloji, Eğitim ve Din Yönüyle İnsanî Değerler, 197.

81 Hökelekli, Din Psikolojisi (Ankara: TDV Yayınları, 2020), 105. 
darda kalmışa yardım elini uzatmaz, uzatamaz. Bunlar, genellikle kendi çıkarlarından başkasını düşünmezler. Böyleleri dinimizin tasvip etmediği beğenilmeyen kişilerdir. Eğer bir toplumun fertleri birbirine güvenmezse, acımazsa, birbirinin malına, canına, namusuna dil uzatırsa, orada huzurdan söz edilemez. Böyle bir toplum hiçbir sorununu rahatlikla çözemez. Oysa vicdan ve karakter sahibi Müslüman ince ruhlu, medeni, ahlaklı, merhametli ve güvenilir bir kişiliğe sahiptir. Nitekim peygamberimiz, Allah bir insanı helak etmek istediği zaman, o kişiden, utanma duygusunu, güvenilirliği ve sonunda merhameti aldığını belirtmektedir. ${ }^{82}$

Başka bir çalışmada ele aldığımız ${ }^{83}$-burada üzerinde fazla durmayacağımız- eğitsel bir kurum olan okul da önemli bir çevredir ve burada arkadaş-akran grubu, öğretmen, yönetici, dersler ve diğer personeliyle çocuklara karakter, vicdan ve ahlaki davranışlar kazandırılmaktadır. Dolayısıyla kontrollü bir ortam ${ }^{84}$ olan okul; eğitsel, toplumsal, kültürel ${ }^{85}$ dinamiklerle ve sosyal etkileşim çerçevesinde çocuğun karakterini, kişiliğini inşa etme imkânına en fazla sahip olan kurumdur. Bu itibarla başta aile olmak üzere çevrede, okulda iyi bir insani ve ahlaki/dini eğitim görmüş olan insanların davranış özellikleri, ahlaki tutumu, görev ve sorumluluk anlayışının ${ }^{86}$ daha bilinçli, düzenli, sorumlu, daha çok vicdanlı ve merhametli olduğu dikkatimizi çekmektedir. Her şeyden önce bu kişiler uyumludur, kavgacı değil uzlaşıcı, uzlaştırıcıdır. İnsanları sever, onlara saygılı davranır. Üretici olmasının yanında paylaşma alışkanlığı da kazanmıştır. Bütün öteki canlılara şefkatle yaklaşır, hiç bir eşyaya, nesneye zarar vermez. Aile ve yakın çevresinin, toplumun geleneklerine ilgi gösterir; düğün, bayram, cenaze törenlerine katılır ve gücü ölçüsünde rol üstlenir. Arkadaşlarının,

82 Ebu Abdilleh Muhammed b. Yezid el-Kazvini İbn Mace, es-Sünen (b.y.: Beyrut: Daru'1Fikr, 1424/2003), "Fiten", 27.

83 Bk. Nedim Öz, “Kimlik ve Karakter Olușumunda Okulun Rolü”, Diyanet İlmî Dergi, 55 (2019).

84 Münire Erden, Ĕ̆itim Bilimlerine Giriş (Ankara: Arkadaş Yayınları, 2017), 22.

85 Zuhal Çubukçu, "İlköğretim Öğrencilerinin Karakter Eğitimi Sürecinde Örtük Programın Etkisi", Kuram ve Uygulamada Eğitim Bilimleri 12/2 (2012), 1514.

86 Sulhi Dönmezer, Sosyoloji (Ankara: Savaş Yayınları, 1982), 214-215; Mustafa Aydın, Kurumlar Sosyolojisi (İstanbul: Açllım Kitap, 2013), 55; Hüseyin Ağca, Ailede Ĕ̆itim (Ankara: Türkiye Diyanet Vakfı Yayınları, 2012), 125-126. 
komşu ailelerin sorunlarına ilgi gösterir ve yardımlarına koşar. Çevresine karşı kaba, katı davranarak onları incitmez. Hak duygusuna sahip olduğundan hiç kimseye haksızlık yapmaz, yapılmasına da tepki gösterir. İnsanı, yaratılmışların en üstün varlığı olarak sevgiye, saygıya değer bulur. İnsan haklarına karşı olumsuz tavır ve tutum sergilemez. İnsan ilişkilerinde kaba kuvvetin ve şiddetin hiçbir işe yaramadığının bilincindedir ve daima uysal, uzlaştırıcı, problem çözücü tavırlar sergiler. Görevini; helal kazanca olan bağlılı̆̆ı, kendine saygısı ve vicdanının huzura ermesi için diş denetim korkusundan uzak olarak yerine getirir. Böylesi bir anlayışa sahip insanların meydana getirdiği toplumda ise, şiddet, taciz ve tecavüz, vicdansızlık, merhametsizlik ve hoşgörüsüzlük istisnai bir durum haline gelir.

\section{Sonuç}

$\mathrm{Bu}$ çllışma, bireylere vicdan ve merhamet kazandırma hususunu, aileyle çevre tarafından güzel ve olumlu örneklerle vermek suretiyle vicdanlı toplum oluşturma sürecini ele almayı amaç edinmiştir. İnsan, maddi ve manevi yönleri eğitimle geliştirilebilen veya sosyalleşebilen bir varlıktır. $\mathrm{O}$, birçok yetenek ve duyguyla birlikte vicdan, acıma ve merhamet duygularına da sahiptir. Doğuştan çatışma, şiddet, saldırganlık ve hoşgörüsüzlük niteliklerine sahip olmayan insan nesli, bu özelliklerini aile ve sosyal muhit içerisinde kazanmaktadır. Şiddet ve terör gibi menfi durumların tesirinde kalmadan yetişen nesillerin oluşturduğu toplumlarda sosyal ilişkiler, daha uyumlu, düzenli, merhamet ve şefkat yüklü ve vicdanlı bir seyir izlemektedir. Bu manada iyiyi kötüden ayıran ve yaratılıştan sahip olunan vicdan, bulunduğu ortama göre köreltilebildiği gibi geliştirilebilme imkânına da sahiptir. Temelleri aile ortamında ve küçük yaşlardan başlayarak atılmaya başlayan vicdanlılık veya vicdansızlık durumları, içinde bulunduğu sosyo-dini ve kültürel çevrede gelişmesini de körelmesini de sürdürme imkânına sahiptir. Sürekli tartışma, kavga, çatışma ve şiddetin yaşandığ bir muhitte değil de, sevgi ve saygının, merhametin, şefkatin, yardımlaşma ve dayanışmanın, paylaşmanın, hoşgörünün yaşandığı bir ailede, okulda ve çevrede yetişen bireyler daha uyumlu, acıma ve vicdan duygusu daha güçlü olduğundan, toplum da daha uymlu olmaktadır. Doğal olarak bu tür bireylerin ekseriyeti oluşturduğu toplumlarda da ilişkiler sevgi ve saygının, merhametin, hoşgörünün, hak ve adalet 
ilkelerinin üzerine bina edileceğinden, şiddet, saldırganlık ve vahşice işlenen cinayetler istisna olacak; bunun sonucunda bireysel, ailevi ve toplumsal huzurla birlikte şiddetin neden olduğu astronomik masraf ve kaynaklar başka alanlara kaydırılabilecektir.

\section{Kaynakça}

Ağca, Hüseyin. Ailede Eğitim. Ankara: Türkiye Diyanet Vakfı Yayınları, 2012.

Ahmed b. Hanbel, Ebû Abdilleh Ahmed b. Muhammed b. Hanbel eşŞeybânî. el-Müsned. Riyad: Beytü'l-Efkar, 1419/1998.

Ahmed b. Hanbel. Müsned. 4 Cilt. b.y.: Riyad: Beytü'l-Efkar, 1998.

Arslantürk, Zeki - Amman, Mehmet Tayfun. Sosyoloji. İstanbul: Çamlıca Yayınları, 2013.

Ay, M. Emin. Çocuklarımıza Allah'ı Nasıl Anlatalım. İstanbul: Timaş Yayinları, 1998.

Aydın, Mustafa. Güncel Kültürel Kavramlar. İstanbul: Açılım Kitap, 2013.

Aydın, Mustafa. Kurumlar Sosyolojisi. İstanbul: Açılım Kitap, 2013.

Aydın, Muhammed Şevki. Ĕ̆̌itim Ahlakı. Ankara: DİB Yayınları, 2020.

Bağçeci, Muhiddin. "Vicdan”. Şamil İslam Ansiklopedisi. 8/234-236. İstanbul: Şamil Yayınevi, 2000.

Baymur, Feriha. Genel Psikoloji. İstanbul: İnkılâp Kitabevi, 1985.

Bolay, Süleyman Hayri. “Aşkın Değerler Buhranı”. Değgerler ve Eğitimi. ed.

Recep Kaymakcan vd.. 55-69. İstanbul: Dem Yayınları, 2013.

Cüceloğlu, Doğan. İnsan ve Davranışı. İstanbul: Remzi Kitabevi, 2018.

Coşkun, Hasan. "Modernleşme Sürecinde Aile'de Kimlik". Kadın ve Aile

Üzerine Araştırmalar Diıi, Tarihi, Sosyolojik ve Psikolojik Analizler, ed.

Emine Öğük. 255-278. Ankara: İlahiyat Yayınları, 2018.

Çă̆an, Kenan. "Ailenin İşlevleri”. Aile Sosyolojisi. ed. Kadir Canatan Ergün Yıldırım. 83-93. İstanbul: Açılımkitap, 2013.

Çağrıcı, Mustafa. Anahatlarıyla İslam Ahlakı. İstanbul: Ensar Neşriyat, 2000.

Çağrıcı, Mustafa. "Ahlaki Müeyyide”. İslam Ahlakı. ed. Muhammed Şevki Aydın - Ahmed Hadi Adanalı. 173-198. İstanbul: DİB Yayınları, 2014. 
392 | N. ÖZ / Vicdanlı Nesilden Vicdanlı Topluma

Çubukçu, Zuhal. “İlköğretim Öğrencilerinin Karakter Eğitimi Sürecinde Örtük Programin Etkisi". Kuram ve Uygulamada Eğitim Bilimleri 12/2 (2012), 1513-1534.

Demir, Osman. "Vicdan". Türkiye Diyanet Vakfı İslâm Ansiklopedisi. 43/100102. Ankara: TDV Yayınları, 2013.

Demir, Ömer - Acar, Mustafa. Sosyal Bilimler Sözlüğü. İstanbul: Ağaç Yayınları, 1992.

Deniz, Gürbüz. Anlam ve Varlık Boyutuyla İnsan. Ankara: DİB Yayınları, 2015.

Doğan, D. Mehmet. Büyük Türkçe Sözlük. İstanbul: İz Yayıncılık, 1996.

Doğan, İsmail. Sosyoloji. İstanbul: Sistem Yayınları, 1998.

Dönmezer, Sulhi. Sosyoloji. Ankara: Savaş Yayınları, 1982.

Durkhim, Emile. Meslek Ahlakı, çev. Mehmet Karasan. İstanbul: Milli Eğitim Basımevi, 1986.

Durkheim, Emile. Ahlak Eğitimi. çev. Oğuz Adanır. İstanbul: Say Yayınları, 2016.

Dündar, Özge Zeybekoğlu. “Değişen ve Değiş(e)meyen Yönleriyle Aile: Yapısı, Türleri, İşlevleri". Değişen Toplumda Değişen Aile Sosyolojik Tartışmalar. ed. Nurşen Adak. 39-64. Ankara: Siyasal Kitabevi, 2018. Erden, Münire. Eğitim Bilimlerine Giriş. Ankara: Arkadaş Yayınları, 2017.

Erkal, Mustafa E. vd.. Ansiklopedik Sosyoloji Sözlüğ̈̈. İstanbul: Der Yayınları, 1997.

Filmer, Paul. "Yüksek/Kitle". çev. M. Ali Kirman - Talip Baycar. Temel Sosyolojik Dikotomiler. ed. Chris Jenks. 468-491. Ankara: Atıf Yayınları, 2014.

Güler, İlhami. İman Ahlak İlişkisi. Ankara: Ankara Okulu Yayınları, 2010.

Günay, Ünver. Din Sosyolojisi. İstanbul: İnsan Yayınları, 2014.

Güngör, Erol. Değerler Psikolojisi. Amsterdam: Hollanda Türk Akademisyenler Birliği Vakfı Yayınları, 1993.

Güngör, Özcan. “Sosyalleşme ve Din”. Din Sosyolojisi. ed. Özcan Güngör - Rıdvan Şimşek. 502-512. İstanbul: Lisans Yayınları, 2020.

Hökelekli, Hayati. Din Psikolojisi. Ankara: TDV Yayınları, 2020.

Hökelekli, Hayati. Psikoloji, Eğ̊itim ve Din Yönüyle İnsanî Değerler. İstanbul: Dem Yayınları, 2013.

İbn Mace, Ebu Abdilleh Muhammed b. Yezid el-Kazvini. es-Sünen. b.y.: Beyrut: Daru'l-Fikr, 1424/2003. 
Karaman, Fikret vd.. Dini Kavramlar Sözlüğü. İstanbul: Diyanet İşleri Başkanlığı Yayınları, 2009.

Karauğuz, Güngör. Âdem'in Çocukları. Konya: Çizgi Kitabevi, 2013.

Kaymakcan, Recep. "Bir Değer Olarak Hoşgörü ve Eğitimi". Değerler ve Ĕgitimi. ed. Recep Kaymakcan vd.. İstanbul: Dem Yayınları, 2013, 515-531.

Koca, Ferhat. "Rahmet ve Merhamet Çağrısı Olarak İslam”. Hz. Peygamber ve Merhamet Ĕ̆itimi. 65-76. Ankara: DİB Yayınları, 2012.

Köylü, Mustafa - Nazıroğlu, Bayramali. "İlköğretimde Din Eğitimi”. Din Eğitimi. ed. Mustafa Köylü - Nurullah Altaş. 149-189. İstanbul: Ensar Neşriyat, 2014.

Köylü, Mustafa. “Ailede Din Eğitimi”. Din Eğitimi. ed. Mustafa Köylü Nurullah Altaş. 309-348. İstanbul: Ensar Neşriyat, 2014.

Kur'an̂n-ı Kerìm Meali, çev. Halil Altuntaş - Muzaffer S,ahin. Ankara: Diyanet İşleri Başkanlığı Yayınları, 12. Basım, 2006.

Leirvik, Oddbjorn. "Hoşgörü, Vicdan ve Dayanışma: Ahlak ve Din Eğitiminde Küreselleşen Kavramlar". Değerler ve Eğitimi. ed. Recep Kaymakcan vd.. 533-552. İstanbul: dem Yayınları, 2013.

Mead, George Herbert. Zihin, Benlik ve Toplum. çev. Yeşim Erdem. Ankara: Heretik Yayınları, 2017.

Mehmedoğlu, Yurdagül. Okul Öncesi Çocuklarda Dinî Duygunun Gelişimi ve Ĕgitimi. Ankara: TDV Yayınları, 2005.

Milli Kütüphane Başkanlığı. Türk Atasözleri ve Deyimleri. 2 Cilt. İstanbul: Milli Eğitim Bakanlığı Yayınları, 1997.

Müslim, Ebü'l-Hüseyn Müslim b. el-Haccâc. el-Câmi'ü's-Sahih. Beyrut: Daru'l-Fikr, 1424/2003.

Öz, Nedim. "İlahiyat Fakültesi Öğrencilerinin Din/İslam ve Şiddet İlişkisini Algılayışı (Kilis 7 Aralık Üniversitesi Örneği). Kilis 7 Aralık Üniversitesi İlahiyat Fakültesi Dergisi 2/3 (2015), 135-187.

Özakpınar, Yılmaz. İnsan Düşüncesinin Boyutları. İstanbul: Ötüken Yayınları, 2002.

Özcan, Ahmet. "İletişimin Önemi". Medya ve İletişim. ed. Hüseyin Özhazar. 17-32. İstanbul: Anadolu Eğitim ve Davet Gönüllüleri Platformu, 2012.

Ritzer, George. Modern Sosyoloji Kuramları. Ankara: De Ki Basım Yayınları, 2011. 
394 | N. ÖZ / Vicdanlı Nesilden Vicdanlı Topluma

Sayar, Kemal. "Hangi Terapi? Çağımızda Benliğin Dönüşümü", Kültür ve Ruh Sağllğı, çev. Sabir Yücesoy. 99-109. İstanbul: Metis Yayınları, 2012.

Sayar, Kemal - Dinç, Mehmet. Psikolojiye Giriş. İstanbul: Dem Yayınları, 2014.

Serinsu, Ahmet Nedim vd.. Din̂̂ Terimler Sözlüğü. Ankara: Milli Eğitim Bakanlığ1 Yayınları, 2009.

Sıla, Bedir. "Uyumdan Çatışmaya: Bir Ara Kurum Olarak Ailenin Sosyalleşme Sürecindeki Rolü". Aile Kurumuna Farklı Bakışlar. ed. Özlem Altunsu Sönmez - Gamze Aksan. 35-52. Konya: Çizgi Kitabevi, 2019.

Sula, Havva. "Rahmet, İsteneni Değil İhtiyaç Duyulanı Vermektir". Hz. Peygamber ve Merhamet Eğitimi. 121-128. Ankara: DİB Yayınları, 2012.

Şerif, Muzaffer. Sosyal Kuralların Psikolojisi. İstanbul: Alan Yayıncılık, 1985.

Taylan, Hasan H. Televizyonla Yetişmek: Televizyon Şiddetinin Etkileri Üzerine Bir Araştırma. Konya: Çizgi Kitabevi, 2011.

Tirmizi, Ebu İsa Muhammed b. İsa b. Sevre. es-Sünen. b.y.: Riyad: Daru'lHadara, 1436/2015.

Topçu, Nurettin. İsyan Ahlakı. çev. Mustafa Kök - Musa Doğan. İstanbul: Dergâh Yayınları, 2006.

Wallace, Ruth A. - Wolf, Alison. Çă̆daş Sosyoloji Kuramları. çev. Leyla Elburuz - M. Rami Ayas. Ankara: Doğu Batı Yayınları, 2012.

Yapıcı, Asım. İslam'da Tövbe ve Dini Yaşayıştaki Önemi. İstanbul: Beyan Yayınları, 1997.

Yavuz, Kerim. Çocukta Dini Duygu ve Düşüncenin Gelişmesi. Ankara: DİB Yayınları, 1983.

Yılmaz, Sinan. Türkiye'de Ailenin Dönüşümü. Ankara: Divan Kitap, 2012. 